\title{
Multinodular vacuolating and neuronal tumor of the cerebrum
}
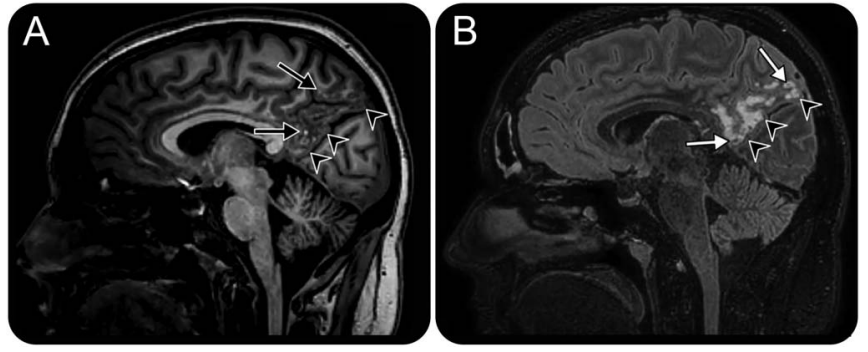

(A) Sagittal T1-weighted imaging and (B) FLAIR MRI. Right parietal lesion involves the deep cortical ribbon and the adjacent subcortical white matter (arrowheads), distributed into small coalescent nodules, hyperintense on FLAIR, hypointense with punctiform hyperintensities (black arrows) on T1-weighted imaging, characteristics of MVNT. Some lesions have a central FLAIR hyposignal (white arrows).

A 31-year-old woman presented with chronic headache. MRI revealed an atypical right parietal lesion involving the deep cortical ribbon and adjacent superficial subcortical white matter (figures 1 and 2).

There was no enhancement after gadolinium injection. Diffusion-weighted imaging, susceptibilityweighted imaging, and dynamic-susceptibility contrast showed no abnormality. Close follow-up was

Figure 2 Magnetic resonance spectroscopy

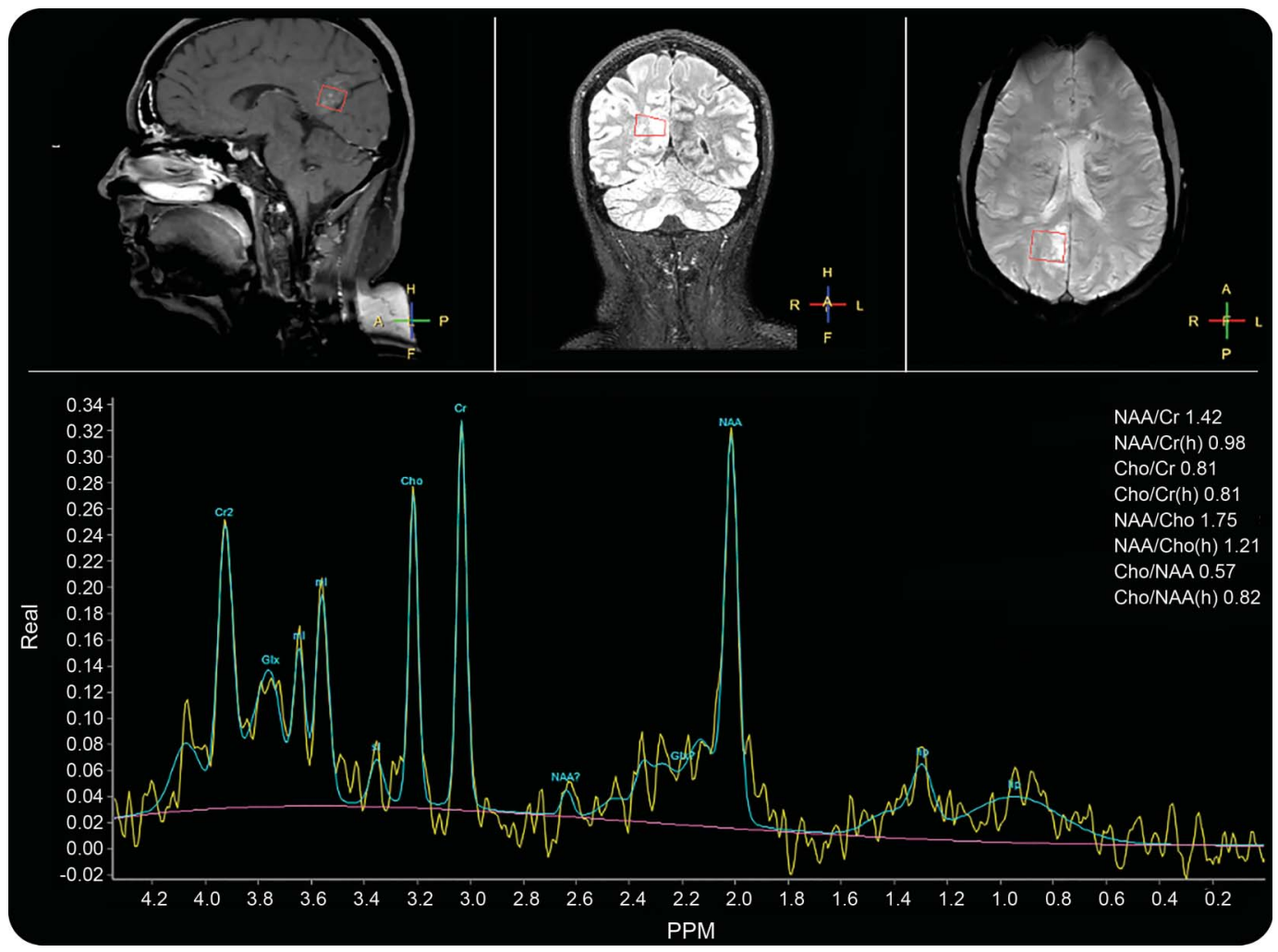

Magnetic resonance spectroscopy shows a mild decrease of NAA. 
performed, showing no changes after 5 years, meaning the diagnosis of multinodular and vacuolating neuronal tumor (MVNT) was most likely. This diagnosis remains presumptive, since there was no pathologic confirmation. MVNT is a benign tumor that has only recently been recognized in the 2016 revision of the WHO classification of CNS tumors. ${ }^{1,2}$

Neesmah Badat, MD, Julien Savatovsky, MD, Frédérique Charbonneau, MD, Adrien Collin, MD,

Augustin Lecler, MD, MSc

From Fondation Ophtalmologique Rothschild, Paris, France.

Author contributions: A. Lecler, N. Badat: study concept and design, acquisition, analysis and interpretation of data. J. Savatovsky, F. Charbonneau, A. Collin: acquisition of data.

Study funding: No targeted funding reported.

Disclosure: The authors report no disclosures relevant to the manuscript. Go to Neurology.org for full disclosures.

Correspondence to Dr. Lecler: alecler@for.paris

1. Fukushima S, Yoshida A, Narita Y, et al. Multinodular and vacuolating neuronal tumor of the cerebrum. Brain Tumor Pathol 2015;32:131-136.

2. Huse JT, Edgar M, Halliday J, Mikolaenko I, Lavi E, Rosenblum MK. Multinodular and vacuolating neuronal tumors of the cerebrum: 10 cases of a distinctive seizure-associated lesion. Brain Pathol 2013;23:515-524.

\section{WriteClick ${ }^{\circledR}$ rapid online correspondence}

Have a comment on a recent $N$ eurology ${ }^{\circledR}$ article you would like to share? Now it is easier and more convenient. Neurology.org has launched WriteClick on the home page and sidebars of each article to encourage remarks and debate among users.

WriteClick is restricted to comments about studies published in Neurology within the last eight weeks.

Learn more at Neurology.org/letters

\section{Discover Altmetrics}

See real-time downloads and online activity for articles!

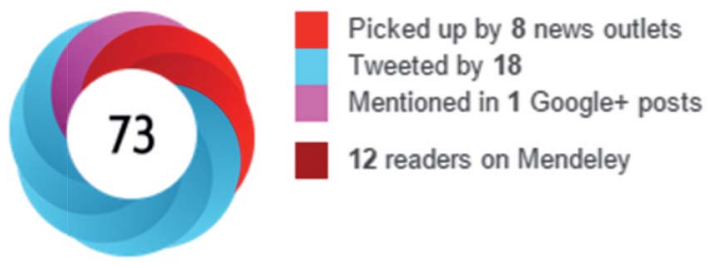

See more details

Authors and readers alike can view real-time data on articles including downloads and online activity across multiple sources. Click on the "Article Metrics" link in the right column of an article for details. To learn more about article metrics visit http://www.neurology.org/site/misc/article_usage.xhtml. 


\title{
Neurology
}

\author{
Multinodular vacuolating and neuronal tumor of the cerebrum \\ Neesmah Badat, Julien Savatovsky, Frédérique Charbonneau, et al. \\ Neurology 2017;89;304-305 \\ DOI 10.1212/WNL.0000000000004123
}

This information is current as of July 17, 2017

$\begin{array}{ll}\begin{array}{l}\text { Updated Information \& } \\ \text { Services }\end{array} & \begin{array}{l}\text { including high resolution figures, can be found at: } \\ \text { http://n.neurology.org/content/89/3/304.full }\end{array} \\ \text { References } & \text { This article cites } 2 \text { articles, } 0 \text { of which you can access for free at: } \\ & \text { http://n.neurology.org/content/89/3/304.full\#ref-list-1 } \\ & \text { This article has been cited by } 1 \text { HighWire-hosted articles: } \\ & \text { http://n.neurology.org/content/89/3/304.full\#\#otherarticles } \\ \text { Citations } & \text { This article, along with others on similar topics, appears in the } \\ & \text { following collection(s): } \\ \text { MRI } & \text { http://n.neurology.org/cgi/collection/mri } \\ \text { Primary brain tumor } & \text { http://n.neurology.org/cgi/collection/primary_brain_tumor } \\ & \text { Information about reproducing this article in parts (figures,tables) or in } \\ & \text { its entirety can be found online at: } \\ & \text { http://www.neurology.org/about/about_the_journal\#permissions } \\ \text { Permissions \& Licensing } & \text { Information about ordering reprints can be found online: } \\ & \text { http://n.neurology.org/subscribers/advertise }\end{array}$

Neurology ${ }^{\circledR}$ is the official journal of the American Academy of Neurology. Published continuously since 1951, it is now a weekly with 48 issues per year. Copyright @ 2017 American Academy of Neurology. All rights reserved. Print ISSN: 0028-3878. Online ISSN: 1526-632X.

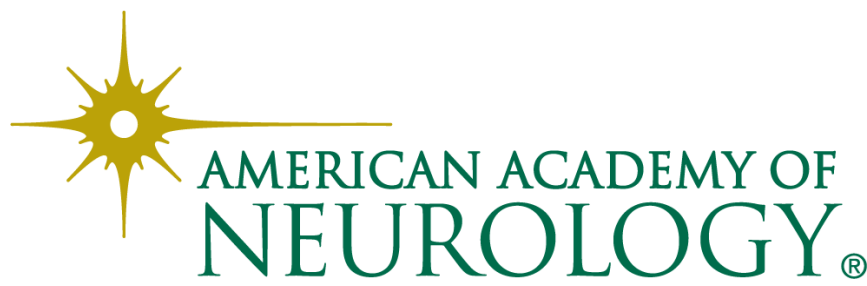

